retort-shaped nests, others again build round balls of grass supported on grass stems, while a few make their nests on the ground. In contradistinction to this variation in nest building one sub-family, the Viduinæ or widow birds, make no nest but lay their eggs in those of small members of the family. Among the true finches there is the Cape canary, Serinus canicollis, and a dozen or so others including the chaffinch now established in the Cape Peninsula. Among the buntings are three species of that widely distributed genus Fringillaria, or rock buntings, ranging from western India to the Cape.

This will prove a very useful work not only for the inhabitants of the Union but also to ornithologists throughout the world. It is much to be regretted that the size of the book had to be limited, and we trust that in the future Dr. Roberts will give us a history of the birds of South Africa.

N. B. Kinnear.

\title{
PRINCIPLES OF MODERN BUILDING
}

\section{(I) Building Design and Construction}

With Reference to the New L.C.C. Regulations. By Felix James Samuely and Conrad Wilson Hamann. Vol. 1. Pp. xi+350. (London: Chapman and Hall, Ltd., 1939.) 25s. net.

\section{(2) The Essentials of Reinforced Concrete Design}

A Simplified Text-Book with Special Reference to both Old and New L.C.C. Regulations, and to the Code of Practice of the Building Research Board. By R. F. B. Grundy. Pp. xi + 134. (London: Chapman and Hall, Ltd., 1939.) 10s. $6 d$. net.

$\mathrm{T}$ HE progress of research in all branches of the building industry has inevitably led to the development of new ideas in both design and construction, and to important modifications in recognized methods. In a report published in October 1938 on behalf of the Department of Scientific and Industrial Research ("Principles of Modern Building", vol. 1, Walls, Partitions and Chimneys) it was explained by Dr. R. E. Stradling, then director of building research, in a foreword, that the aim in preparing it was to set out a statement of principles to guide the practical man in adapting his designs to the changes which have been taking place. For about eighteen years, the Building Research Station has been investigating materials and methods and collecting data. Scientific developments, increasing experience and new trends in architecture have led to the codification of new rules, and there are now available for the guidance of designers and constructors the code of practice prepared by the Building Research Board and the new regulations of the London County Council.

Such a position makes necessary the provision of new text-books and hand-books on the branches of the building industry which are affected. Both the volumes referred to at the head of this notice take the new regulations as their basis. Indeed, the first mentioned may be said to have actually arisen out of them.

(1) The authors, finding it necessary to prepare a new set of explanatory notes, tables and sketches for use in the drawing office to meet the requirements of the authorities, took the public-spirited step of making them generally available.

In this, the first of the three volumes in question, the greater part is devoted to technical explanations of the by-laws, accompanied by sketches, tables, specifications and graphs. A section has been given to a short résumé of the enactments to which buildings in London must conform, and the final portion contains an important chapter on monolithy. Here the aim is to explain the monolithic action of continuous framework, so that the designer may be enabled to estimate stresses with sufficient accuracy to ensure that the material is satisfactorily distributed and the factor of safety is constant, or at least approximately so. The tables which are provided enable the work to be carried out expeditiously.

(2) It is on a more modest scale that the subject of the second book is presented, and it is intended more particularly to meet the requirements of those engaged in the design of the simpler types of reinforced concrete structures. By reason of its concise and practical method of presentation and the side-by-side development of theory and practice, it should also prove a textbook of real value to the student. The most important feature of a book of instruction is that it should give its reader a thorough and reliable grounding in its subject. In the case of such elementary problems as arise in columns, slabs, T-beams, retaining walls and foundations, it provides that measure of practical guidance that is most desired by the student or junior designer. 